\title{
Viticultural performance of Cabernet Sauvignon clones in highland region of southern Brazil
}

\author{
José Luiz Marcon Filho ${ }^{1}$, Leo Rufato², Amauri Bogo ${ }^{2 *}$, Tiago Afonso De Macedo ${ }^{1}$, \\ Douglas André Würz ${ }^{1}$, Aike Anneliese Kretzschmar ${ }^{2}$
}

\begin{abstract}
The Cabernet Sauvignon (CS) cultivar is one of the most widely planted wine grapes in Brazil. The final grape quality depends on the clone type, rootstock, and the terroir. This study aims to assess and characterize the effects of seven combinations of CS clones grafted onto two rootstocks on the physical-chemical parameters and productivity of the grapes in the highland of southern Brazil, during the 2012-2013, 2013-2014, 2014-2015, and 2015-2016 growing seasons. The experiment was carried out in a 14-year-old commercial vineyard, located in São Joaquim municipality, Santa Catarina State, trained on a vertical shoot position system on a double cordon with spur pruning. The treatments consisted in a completely randomized experimental block of the combination (clone/rootstock) of CS 169, 337, 341, and R5 clones grafted onto the Paulsen 1103 (P1103) rootstock, and 169, 170, and 339 clones grafted onto the Courdec 3309 (C3309) rootstock. There were significant differences among the combinations of CS grapes on productivity, physical, and chemical parameters and grape maturation. The data of principal component analysis showed that 339/C3309 and 337/P1103 combinations were the most productive, whereas the R5/ P1103, 170/C3309, and 169/C3309 combinations were the best for potential winemaking under the edaphoclimatic conditions of the highlands of southern Brazil in all growing seasons evaluated.
\end{abstract}

Index terms: Vitis vinifera; clonal selection; rootstock; grape composition; yield components.

\section{Desempenho vitícola de clones de Cabernet Sauvignon em região de altitude do sul do Brasil}

Corresponding author: amauri.bogo@udesc.br

Received: April 15,2019 Accepted: July 30,2019

Copyright: All the contents of this journal, except where otherwise noted, is licensed under a Creative Commons Attribution License.

\section{$(\mathrm{cc}) \mathbf{\mathrm { EY }}$}

Resumo - A cultivar Cabernet Sauvignon é uma das videiras para vinho mais amplamente cultivada comercialmente no Brasil. Seu desempenho em relação à qualidade final da uva depende do clone, do porta-enxerto e do "terroir" onde os vinhedos estão localizados. Este estudo teve como objetivo avaliar e caracterizar os efeitos de sete combinações de clones de videira Cabernet Sauvignon enxertados em dois porta-enxertos sobre a produtividade e os parâmetros físico-químicos das uvas em região de altitude do Sul do Brasil, durante as safras de 2012-2013, 2013-2014, 2014 -2015 e 2015-2016. Os experimentos foram conduzidos em um vinhedo comercial com 14 anos de idade, localizado no município de São Joaquim, Santa Catarina, conduzido em sistema de espaldeira, em duplo cordão esporonado. Os tratamentos consistiram na combinação (clone/porta-enxerto) dos clones de Cabernet Sauvignon 169; 337; 341 e R5 sobre o porta-enxerto Paulsen 1103 (P1103), e dos clones 169, 170 e 339 sobre o porta-enxerto Courdec 3309 (C3309). Houve diferenças significativas entre as combinações dos clones de videira Cabernet Sauvignon com os portaenxertos, afetando os parâmetros produtivos, físicos, químicos e o período de maturação da uva. As combinações 339 / C3309 e 337 / P1103 apresentaram maiores produtividades, enquanto as combinações R5 / P1103, 170 / C3309 e 169 / C3309 apresentaram maior potencial para produção de vinho, quando os parâmetros físicos, químicos e de produtividade foram considerados nas condições edafoclimáticas de região de altitude do Sul do Brasil, em todas as safras avaliadas.

Termos para Indexação: Vitis vinifera; seleção clonal; porta-enxertos; composição da uva; componentes de produção.

\footnotetext{
${ }^{1}$ Acadêmico do Programa de Pós-Graduação em Produção Vegetal, CAV/UDESC. Lages - SC, Brasil. E-mail: marconfilho_jl@ yahoo.com.br (ORCID 0000-0001-8198-378X); macedoafonso@yahoo.com.br; douglaswurz@hotmail.com (0RCID 0000-0001-6109-9858) ${ }^{2}$ Professores do Programa de Pós-Graduação em Produção Vegetal, CAV/UDESC. Lages - SC, Brasil. E-mail: leo.rufato@udesc. br (ORCID 0000-0001-9545-7035); amauri.bogo@udesc.br (ORCID 0000-0002-2766-2042); aikeanneliese@yahoo.com.br
} 


\section{Introduction}

The highland region of Santa Catarina State, southern Brazil, has emerged as a center of altitude wine production, mainly due to its edaphoclimatic features. This region has high levels of sunlight, moderate temperatures during the day, and low temperatures at night. These conditions enable the growth of fine wine grapes (Vitis vinifera L.) with high physical, chemical, and enological performance (BORGHEZAN et al., 2014; MARCON FILHO et al., 2015; MALINOVSKI et al., 2016; WURZ et al. 2017). Among the grapes produced in this region, cultivation of the 'Cabernet Sauvignon' varieties represents approximately $40 \%$ of the total area of vineyards (VIANNA et al., 2016). Cabernet Sauvignon is one of the varieties with the longest vegetative-productive cycle, with an average of 214 days, and it demands a higher thermal requirement to complete all its phenological stages. The harvest usually starts after mid-April (BRIGHENTI et al., 2013), when the average temperature drops to $14^{\circ} \mathrm{C}$, according to the historical climatic series (EPAGRI , 2019). Based on these climatic conditions, especially in rainy and cold years, there is a threat to the harvest of Cabernet Sauvignon grapes associated with inadequate maturation parameters, such as high acid content and excessive herbaceous aroma (WURZ et al., 2017). Furthermore, all these peculiar edaphoclimatic conditions, associated with high water availability and high organic matter content $(>3.5 \%)$, promote excessive vegetative growth impairing the production and quality of wine grape (ZALAMENA et al., 2013; MARCON FILHO et al., 2015).

Vitis vinifera clones are generally selected for genetic resistance to pests and diseases, associated with specific chemical characteristics. Phenotypic variations among these chemical characteristics are often observed among clones of the same variety, and can appear before or after berry ripening (ZAMUZ et al., 2007). Some clones of one grape variety can differ in their productivity parameters and their ability to produce wines with different organoleptic characteristics (GÓMEZ-PLAZA et al., 2000; ZAMUZ et al., 2007). Clonal selection has led to significant gains in grape production, together with improvements in grape and wine quality (BURIN et al., 2011). The selection of the best germplasm bank material for a specific grape-growing region is a fundamental step toward improving grape yield and fruit composition (FIDELIBUS et al., 2006). Several studies showed that different clonal selections of Cabernet Sauvignon presented differences in their chemical composition and productive variables (ALONSO et al., 2004; FALLAHI et al., 2005; FIDELIBUS et al., 2006, ZAMUZ et al., 2007 and BURIN et al., 2011).

When choosing the clone scion variety, it is necessary to consider the best combination between scion and rootstock, according to the terroir characteristics. Rootstocks play an important role in adapting to environmental factors; they also have an impact on canopy development, which can influence the amount and quality of production (RENOUF et al., 2010; BRIGHENTI et al. 2011; SOUZA et al., 2015 and DIAS et al., 2017). Grape production in the highlands of southern Brazil is based mainly on the Paulsen 1103 (P1103) rootstock (VIANNA et al., 2016). In this region, the edaphoclimatic conditions can predispose vines to an excessive vegetative growth due to high organic matter (MAFRA et al., 2011; ZALAMENA et al., 2013) and high water availability (DE BEM et al., 2016). Therefore, it is necessary to adjust the vigor of the vegetative canopy to promote the balance of the vineyard as suggested by Borghezan et al. (2011). Additional studies are necessary to show alternative rootstocks for this region, mainly those that decrease the vigor of the vines. According to Brighenti et al. (2011), the rootstock Couderec 3309 (C3309) and Mgt 101-14 are good options to reduce the grape canopy vigor in the highlands of Santa Catarina State. The authors showed that these rootstocks present a better balance between the vegetative and productive parts of the vines rootstock, and revealed its positive influence on the productivity and quality of the grapes for fine wine production. However, other grafting combinations need to be evaluated to improve the vineyard management for red winemaking in the highlands of Santa Catarina State, southern Brazil.

Thus, the present study aims to assess and characterize the effects of seven combinations (clone/ rootstock) of Cabernet Sauvignon on productivity and physical-chemical parameters of the grapes in the highlands of Santa Catarina State, southern Brazil, during the four growing seasons.

\section{Materials and methods}

Experiments were carried out in a 14-year-old commercial vineyard of Cabernet Sauvignon, located in São Joaquim municipality, Santa Catarina State, southern Brazil, during the 2012-2013, 2013-2014, 2014-2015, and 2015-2016 growing seasons. The vineyard was located at $28^{\circ} 17^{\prime} 39^{\prime \prime} \mathrm{S}, 49^{\circ} 55^{\prime} 56^{\prime \prime} \mathrm{W}$ and an altitude of $1.230 \mathrm{~m}$. The climate of this region is considered to be humid mesothermic (Cbf), according to the Köppen classification (ALVARES et al., 2013), and the soil type is cambisol, which is characterized by high levels of clay $\left(492 \mathrm{~g} \mathrm{~kg}^{-1}\right)$ and organic matter $\left(69 \mathrm{~g} \mathrm{~kg}^{-1}\right)$. The historical heliothermic index used to 1.714 , average annual rainfall of $1.621 \mathrm{~mm}$, and relative humidity of $80 \%$ (TONIETTO \& CARBONNAU, 2004). The daily data of temperature and precipitation were accomplished and obtained from CI RAM (Center of Environmental Resources Information and Hydrometeorology of Santa Catarina). 
There were approximately 450 vines per vineyard in 60-70 rows of the Cabernet Sauvignon clones 169, 337,341 , and R5 grafted onto the P1103 rootstock, and 169,170 , and 339 grafted onto the $\mathrm{C} 3309$ rootstock. The combinations of Cabernet Sauvignon clones/rootstock were planted in rows with a northwest-to-southeast orientation at a distance of $3.0 \times 1.5 \mathrm{~m}$. Vines were trained onto a vertical shoot position trellis on a double cordon with spur pruning at a height of $1.2 \mathrm{~m}$ and covered with an anti-hail net. A completely randomized experimental block was used, which consisted of eleven vines along the rows. These conditions were replicated four times for each treatment and each treatment was separated by buffer rows. Three vines at the end of each plot, vines at the end of each row, and all vines in border rows were excluded. Vineyard practices (pruning, leaf removal, shoot topping, and disease control) were done according to the recommendations for commercial growers in this region. Vineyards were irrigated by drip as usually recommended for commercial growers in this region $(20 \mathrm{~L} /$ day/plant $)$ (BRASIL, 2013).

The monitoring of grape ripening began at veraison, when approximately $50 \%$ of the berries had turned red. Each sample consisted of a total of 10 clusters and 150 berries randomly collected per plot/treatment from different portions of the vine on both sides of the rows for each clone.

The samples were analyzed according to the procedures of the Office International de la Vigne et du Vin (OIV., 1990) for the following physical parameters: a. cluster mass (g); b. berries per cluster; c. compactness index (berries per cluster length); d. 100-berry mass (g); e. berry diameter $(\mathrm{cm})$, and $\mathrm{f}$. skin:berry ratio (\%). All berries were manually crushed one by one to obtain grape must and skin separately.

The total soluble solid (TSS) content $\left({ }^{\circ} \mathrm{Brix}\right)$ of grape was determined using a digital temperaturecompensated refractometer (model Pal-1; Atago, Saitama, Japan); titratable acidity (mg of tartaric acid $100 \mathrm{~g}^{-1}$ grape skin) (Oiv, 2009) and $\mathrm{pH}$ were measured with a potentiometer (Impac, São Paulo, Brazil). Total polyphenols (TP; mg gallic acid $100 \mathrm{~g}^{-1}$ grape skin) (SINGLETON and ROSSI, 1965) and total monomeric anthocyanins (mg malvidin 3-glucoside $100 \mathrm{~g}^{-1}$ grape skin) (GIUSTI and WROLSTAD, 2001) were determined using extracts from grape skin macerated for 24 hours at $30 \pm 0.5^{\circ} \mathrm{C}$ and then washed with methanol: $\mathrm{HCl}$ (99:1).

A second extraction with the remains of the skin was performed with the same methanol volume at temperature of $0 \pm 0.5^{\circ} \mathrm{C}$. Both extracts were separated, homogenized, and filtered through Whatman 01 filter paper (MARCON FILHO et al., 2015). The TP concentration was determined by a spectrophotometric method described by Singleton and Rossi (1965), using the Folin-Ciocalteu reagent, with absorbance at a wavelength of $760 \mathrm{~nm}$. The phenolic content was determined using a gallic acid calibration curve. Total anthocyanins were determined by a spectrophotometric method described by Ribéreau-Gayon et al. (1998). The color was determined by a spectrophotometric method described by Rizzon, (2010). The extract was diluted 1:10 with distilled water and analyzed in a spectrophotometer at wavelengths of 420,520 , and $620 \mathrm{~nm}$. The color was measured by the intensity and color tone parameters using the following formulas: intensity $=420+520+620 \mathrm{~nm}$ and color tone $=420 / 520 \mathrm{~nm}$.

The number of clusters per vine, pruning weight $(\mathrm{kg})$, production $\left(\mathrm{kg} v \mathrm{vine}^{-1}\right)$, and yield $\left(\mathrm{t} \mathrm{ha}^{-1}\right)$ were assessed in 10 plants per plot/treatment. The pruning weight was assessed in the winter during the dormant period. The Ravaz index was estimated using the relationship between production and pruning weight. The fertility index (number of clusters per shoot) were evaluated by counting the number of shoots and number of cluster per vine in 10 plants per plot/treatment.

All analyses were carried out in triplicate. Homogeneity of variance was performed prior $\mathrm{F}$ test for each year. Linear regression; analysis of variance; principal component analysis (PCA); and Tukey-Kramer HSD test at $5 \%$ were performed using the SAS software, version 9.1 (SAS Institute, Cary, NC, USA).

\section{Results}

The average monthly temperature was similar among all growing seasons evaluated (Figure 1). However, the average monthly rainfall were significant different (Figure 1). The average temperature in August (sprouting) was around $10-11{ }^{\circ} \mathrm{C}$, reaching around 17-18 ${ }^{\circ} \mathrm{C}$ in mid-January (grape maturation) and decreased to approximately $13-14^{\circ} \mathrm{C}$ at the end of April (harvest), which can be considerate low when compared with others Brazilian grape production area. The average of high temperatures during all growing seasons evaluated from veraison (January-February) to harvest (March-April) was around $23^{\circ} \mathrm{C}$ (Figure 1).

The rainfall volume from August (sprouting) until the end of April (harvest) in all growing seasons evaluated, was higher than the historical mean $(1.441 \mathrm{~mm})$ for this period in São Joaquim, SC. The rainfall during the maturation period in all growing season was significant different from the historical average, which was around $314 \mathrm{~mm}$ (figure 1).

In all growing seasons, there were few significant differences $(p \leq 0.05)$ among combinations (clone/ rootstock) of Cabernet Sauvignon for the yield components (Table 1). The 337/P1103 and 339/C3309 combinations showed the highest number of clusters per vine, production per plant, yield, and Ravaz and fertility index $(p \leq 0.05)$ 
(Table 1). However, significant differences were observed between physical and chemical variables in all growing seasons evaluated (Table 2, 3 and 4). There were significant differences $(p \leq 0.05)$ among combinations for the variables of cluster mass, berries per cluster, 100-berry mass, and skin:berry ratio in all growing seasons evaluated, whereas there was no effect of treatments on berry diameter (Table 2). The 337/P1103 and 339/C3309 combinations showed the highest cluster mass, berries per cluster, and compactness index during the most of evaluated growing seasons, while the combination 169/C3309 showed the lowest values for these two physical parameters as well as for the variables of 100-berry mass, and skin:berry ratio (Table 2). The R5/P1103 and 170/C3309 combinations showed significantly higher values of TSS in all growing seasons (Table 3). The combinations R5/P1103, 169/ C3309, and 170/C3309 showed the lowest total acidity, pH and the highest values of TP, anthocyanins, and berry color by both intensity and hue (Table 3 and 4 ) as compared to other combinations.

Principal component analysis (PCA) was carried out with data on physical, chemical, and productivity parameters of all grapes at harvest, in order to verify which parameters best discriminated the Cabernet Sauvignon combinations of clones and rootstocks during all growing seasons. There were significant difference $(\mathrm{p} \leq 0.05)$ among all physical, chemical, and productivity parameters (Figures 2 and 3). The principal components CP1 and CP2 explained $88.49 \%$ and $100 \%$ of the total variation of the clones grafted onto the P1103 and C3309 rootstocks, respectively (Figure 2 and 3 ). The contributions of CP1 and CP2 to the total variation were $71.69 \%$ and $53.88 \%$, and $16.80 \%$ and $46.12 \%$ (Figure 2 and 3 ) for all clones grafted onto the $\mathrm{P} 1103$ and $\mathrm{C} 3309$ rootstocks, respectively. CP1 was the component that best discriminated the clones grafted onto P1103 (Figure 2). The projection of the treatments onto the main component plane reveals that the $\mathrm{R} 5$ clone presents a strong association with the variables related to the $\mathrm{PC} 1$ plane with a negative score of 4.97, having strong relations with cluster mass, berries per cluster, compactness index, berry color intensity, TP, TSS, and anthocyanins (Figure 2). Clone 337 showed stronger relationships with the $\mathrm{PC} 1$ plane, with a positive score of 3.37 and with the PC2 plane with a negative score of 2.03, being more associated with the variables of berry diameter, 100-berry mass, skin:berry ratio, production, yield, Ravaz and fertility index, $\mathrm{pH}$, and number of clusters per vine (Figure 2). Clone 169 showed positive relationships with the PC1 and PC2 planes, with scores of 1.81 and 1.61 , respectively, having stronger associations with the variables of acidity, $\mathrm{pH}$, berry diameter, 100-berry mass, yield, and production (Figures 2). Clone 341 presented a positive correlation with the PC2 plane (score 1.01), and a negative correlation with the PC1 plane (score 0.017), being more associated with berry diameter, 100-berry mass, and $\mathrm{pH}$ (Figure 1). Clone 170 showed a positive relationship with the $\mathrm{PC} 1$ plane (score 3.32) and a negative relationship with the PC2 plane (score of 1.27), being more associated with the variables 100-berry mass, cluster mass, berry color tone, berry diameter, total acidity, skin:berry ratio, berries per cluster, soluble solids, and TP (Figure 3). Clone 169 showed negative relationships with both planes, with scores of 2.85 and 2.02 for PC1 and PC2, respectively, being associated with the variables of compactness index, anthocyanins, berry color tone, soluble solids, TP, pH, and berries per cluster (Figures 2 and 3 ). Clone 339 showed a stronger positive correlation with the PC2 plane (score 3.29) and a negative correlation with the PC1 plane (score 0.47 ), being associated with the variables of number of clusters per vine, RI, fertility index, yield, and production (Figure 3).

\section{Discussion}

To assess and characterize the effects of several combinations (clone/rootstock) of Cabernet Sauvignon on the productivity and physical-chemical parameters of the grapes was the main concern about this study, in order to guide appropriate management for winemaking in highlands of Santa Catarina State, southern Brazil. The Principal Component Analysis (PCA) shows that the rootstock effect on the productivity and winemaking composition of the Cabernet Sauvignon clones must varied from year to year. The 337/P1103 and 339/C3309 combinations showed the best productivity parameters according to PC1 and PC2 of the PCA analysis. These two combinations showed the highest number of clusters per vine, production per plant, yield, and Ravaz and fertility indices. Both rootstock P1103 and C3309 showed positive and negative correlation in the PCA analysis, and there were no specific effect on the productivity and winemaking parameters. Although there have been different effects of rootstock in the Cabernet Sauvignon clones each year, it can be seen that the R5/P1103, 169/C3309 and 170/ C3309 combinations had higher levels of 100-berry mass, cluster mass, berry color tone, berry diameter, total acidity, skin:berry ratio, berries per cluster, soluble solids, and TP in all evaluated season. This behavior may have been due to the low to medium vigor of these rootstocks, which favors a relatively earlier grape maturity. On the other hand, it was found that the rootstocks effect on the other assessed variables was erratic year to year. Based on the average data of four years, the two main PCs (Figure 2 and 3 ) show that, in general, $\mathrm{pH}$, berry diameter, 100-berry mass, yield, production, and acidity ratio values were higher with R5/P1103, 169/C3309 and 170/C3309 combinations.

All productivity parameters are important. However, the Ravaz index is one of the most relevant. The 
Ravaz index is the ratio between fruit yield and pruning weight removed in the dorment period. This index is also used to determine vine balance and vigor. According to Smart and Robinson (1991), fruit: pruning-weight ratio of 5 to 10 has been used as an indicator of balanced vines capable of producing high-quality fruit. An index higher than 10 indicates an excessive yield and one less than five indicates excessive vine vigor. Based on the PCA analysis the 337/P1103 and 339/C3309 combinations would be well balanced. However, the R5/P1103, 169/ C3309 and 170/C3309 combinations showed the best quality winemaking parameters.

These results suggest that these combinations were more well balanced than 337/P1103 and 339/C3309 combinations. These results are very interesting and important for highlands of Santa Catarina state, since there are few studies under this edaphoclimatic conditions. Probably there was more equilibrium between leaf area and grape production for R5/P1103, 169/C3309 and 170/ C3309. In contrast, the leaf area of 337/P1103 and 339/ C3309 combinations was not enough to adequately ripen the fruit in terms of accumulation of soluble solids, or the excessive vegetative vigor could have increased the photoassimilate competition between berries and shoots, or have altered the microclimatic conditions at cluster zone impairing the sugar accumulation and phenolic compounds in grapes.

Most of the combinations showed high acidity of berries that could be attributed either by low temperature $\left(13-14{ }^{\circ} \mathrm{C}\right)$ at the harvest time (Figure 1) or, by less sun exposure of the cluster caused by excessive vegetative vigor. It well known that the total acidity tends to be lower and $\mathrm{pH}$ higher in hot environment or sun exposed cluster as compared to berries from shaded conditions or cold. The organic acid degradation tends to reduce with the decrease in temperature and, probably, was the main reason for the high acidity of the berries in most of the combinations. In general, wine quality is attributed to the sugar-acid balance; hence, acidity adjustment is a prerequisite in many wine cellars (TITA et al., 2006). Although total acidity is crucial in wine, all individual organic acids, such as succinic, pyruvic, acetic, citric, lactic, tartaric and malic acid play a crucial role in defining the organoleptic character of the wine. They are important elements of the wine because of their sensory attributes (e.g. sour, sharp, tart, vinegar aroma, metallic and fresh) and their overall contribution to wine acidity (MATO et al., 2005).

The 337/P1103 and 339/C3309 combinations showed the highest yield due to the increased fertility index, cluster number per vine, cluster weight and berries per cluster. These results corroborate the findings of Brighenti et al. (2012), who evaluated the isolated effects of several Cabernet Sauvignon clones from Australia and Brazil, respectively. The authors found significant differences in these physical parameters among Cabernet
Sauvignon clones, and these results corroborated with those reported by Alonso et al. (2004) and Burin et al. (2011), who observed variability between clones of the 'Albariño' variety in Spain and the Cabernet Sauvignon variety in Brazil.

The occurrence of cold nights and mild temperatures during the day (Figure 1), characteristic of the highlands of Santa Catarina State, contribute, according to GonzalesNeves et al. (2004) and Brighenti et al. (2013), for the accumulation of sugars and polyphenolic compounds, especially anthocyanins. The average of high temperatures during from veraison to harvest, of approximately $21^{\circ} \mathrm{C}$, is considered an important factor for plant physiology, since it influences photosynthesis/respiration balance and, consequently, the accumulation of energy for grape development during this period (JACKSON et al., 2014).

The compactness index and berry diameter were relatively high, with averages of 5.92 and 1.34 , respectively. Despite no significant differences being observed in the compactness index and berry diameter among all the Cabernet Sauvignon combinations, there were strong correlations between berry rot incidence and cluster compactness (HED et al., 2009). Thus, compact clusters could be an important problem in the highlands of Santa Catarina State, due to the weather conditions that promote this, such as high precipitation and humidity during ripening and the harvest period. Under these conditions, the 337/1103P and 339/3309 combinations should be avoided, because they showed the highest compactness index.

Most of the Cabernet Sauvignon combinations evaluated showed a high skin:berry ratio, except the 169/C3309 combination. In the making of red wine, the higher the skin:berry ratio, the higher the grape's potential to provide enological quality to the wine, because, according to Conde et al. (2007), desirable compounds such as anthocyanins and polyphenols are located in the skin. Additionally, Battistutta et al. (2000), evaluating 12 Cabernet Sauvignon clones in Italy, confirmed that there were higher values of soluble solids in the R5 and 170 clones, grafted onto the $\mathrm{P} 1103$ rootstock. Wine quality is directly correlated to the physical/chemical composition of grapes at harvest. These parameters are influenced by various factors linked to climate, soil, clone, and rootstock (JACKSON et al., 2014). One of the most important parameters used to determine grape quality is the content of soluble solids, which allows an indirect measure of the sugar content of berries and alcohol content in wine.

R5/P1103, 169/C 3309, and 170/C3309 combinations showed the highest values of soluble solids and the lowest total acidity. These results showed the high chemical potential of grapes from these combinations, which had the best technological maturity, promoting high-quality winemaking. In general, for the production of red wines with high quality is recommended a most with 
soluble solids with concentration of soluble solids above $20^{\circ}$ Brix (GIL \& PSZCZOLKOWSKI, 2007) and total acidity lower than $135 \mathrm{meq} \mathrm{L}^{-1}$ (JACKSON \& LOBARD, 1993). These same combinations had the best anthocyanin and berry color (intensity and hue) performances. These skin features are for most of the $V$. vinifera grapes for red wine, responsible for pigmentation, flavor, and aroma (LECAS \& BRILLOUET, 1994), and the vacuoles of hypodermic cells of the skin contain the anthocyanins (FERNÁNDEZ-LOPEZ et al., 1998). It is widely accepted that the concentration of anthocyanins in wine is related to the final quality of the product because these pigments and wine color intensity are positively correlated. In addition, the relationships of anthocyanin and polyphenolic compounds with wine quality are extremely important, especially in wines with the potential for aging and ripening (TARDAGUILA et al., 2010). The increase in TP compounds is associated with the stage of mature grapes
(GONZALEZ-SANJOSE et al., 1991). On the basis of this assumption and verifying the TP values in Table 4 , it can be inferred that the R5/P1103, 169/C3309, and 170/ C3309 combinations provide the best grape maturation when compared with all the other combinations. Falcão et al. (2008) and Burin et al. (2011) showed that grapes grown in the highlands of Santa Catarina State, southern Brazil, had particular characteristics that differ from those in other wine-growing regions of Brazil. Thus, the wines produced in this region have higher color intensity and a higher concentration of polyphenolic compounds than wines produced in other wine-growing regions of Brazil (MIELE et al. 2010) and elsewhere. Stefanini et al. (2000), who evaluated five clones of Cabernet Sauvignon in northeast Italy, showed that clone 337, which present higher color intensity and a higher concentration of polyphenolic compounds, was the one with the major productive characteristics.
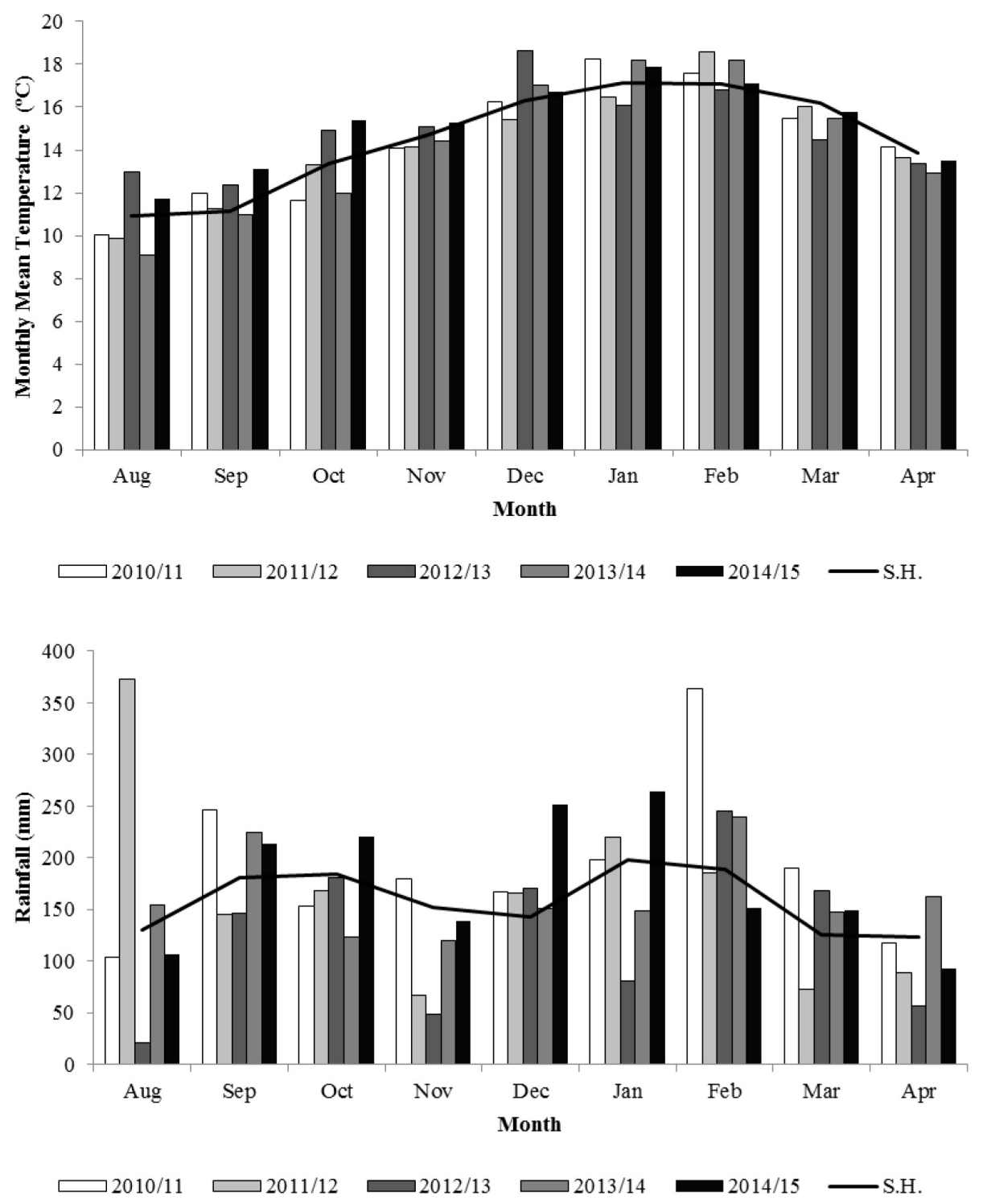

Figure 1. Monthly mean of temperatures $\left({ }^{\circ} \mathrm{C}\right)$ and rainfall $(\mathrm{mm})$ recorded at São Joaquim/SC municipality from August (sprouting) to April (harvest) of the 2010, 2011, 2012, 2013, 2014 and 2015 growing seasons and Historical Series (S.H.) of EPAGRI/CIRAM (2019). 
Table 1- Productivity parameters of different combinations of 'Cabernet Sauvignon' clones 169, 337, 341 and R5 grafted onto 'Paulsen 1103' (P1103) rootstock and clones 169, 170 and 339 grafted onto 'Courdec 3309' (C3309), during the 2012, 2013, 2014 and 2015 growing season. São Joaquim, Santa Catarina State, Brazil, 2019.

\begin{tabular}{|c|c|c|c|c|c|c|}
\hline \multirow{2}{*}{ Combination } & \multirow[b]{2}{*}{ Season } & \multicolumn{5}{|c|}{ Productivity parameters } \\
\hline & & Cluster per vine & Production $\left(\mathrm{kg}\right.$ vine $\left.^{-1}\right)$ & Yield $\left(\mathrm{t} \mathrm{ha}^{-1}\right)$ & Ravaz index & Fertility index \\
\hline \multirow{4}{*}{ 169/P1103 } & 2012 & $20 \pm 1.61 \mathrm{~B} \mathrm{~ns}^{*}$ & $3.9 \pm 0.89 \mathrm{C} \mathrm{b}$ & $8.6 \pm 0.90 \mathrm{C} \mathrm{ns}$ & $3.2 \pm 0.15 \mathrm{~B} \mathrm{~ns}$ & $1.0 \pm 0.08 \mathrm{~A} \mathrm{~ns}$ \\
\hline & 2013 & $23 \pm 2.25 \mathrm{~B}$ & $4.4 \pm 0.72 \mathrm{C} \mathrm{a}$ & $9.7 \pm 2.55 \mathrm{C}$ & $3.4 \pm 0.71 \mathrm{~B}$ & $0.8 \pm 0.07 \mathrm{~B}$ \\
\hline & 2014 & $21 \pm 4.97 \mathrm{~B}$ & $4.0 \pm 0.68 \mathrm{C} \mathrm{ab}$ & $8.8 \pm 2.31 \mathrm{C}$ & $3.3 \pm 0.71 \mathrm{~B}$ & $0.7 \pm 0.10 \mathrm{~B}$ \\
\hline & 2015 & $19 \pm 4.21 \mathrm{C}$ & $3.7 \pm 0.44 \mathrm{D} \mathrm{b}$ & $8.2 \pm 3.67 \mathrm{C}$ & $2.9 \pm 0.71 \mathrm{~B}$ & $0.8 \pm 0.05 \mathrm{~B}$ \\
\hline \multirow{4}{*}{ 337/P1103 } & 2012 & $31 \pm 1.48 \mathrm{~A} \mathrm{~ns}$ & $6.0 \pm 0.45 \mathrm{~B} \mathrm{a}$ & $13.3 \pm 1.43 \mathrm{~A} \mathrm{~ns}$ & $5.8 \pm 0.20 \mathrm{Ab}$ & $1.3 \pm 0.09 \mathrm{~A} \mathrm{~ns}$ \\
\hline & 2013 & $36 \pm 4.24 \mathrm{~A}$ & $6.4 \pm 0.63 \mathrm{~A} \mathrm{a}$ & $14.2 \pm 1.12 \mathrm{~A}$ & $6.9 \pm 0.04 \mathrm{~A} \mathrm{a}$ & $1.4 \pm 0.11 \mathrm{~A}$ \\
\hline & 2014 & $30 \pm 3.35 \mathrm{~A}$ & $5.8 \pm 0.88 \mathrm{~A} \mathrm{ab}$ & $12.8 \pm 2.93 \mathrm{~A}$ & $5.8 \pm 0.20 \mathrm{Ab}$ & $1.2 \pm 0.05 \mathrm{~A}$ \\
\hline & 2015 & $28 \pm 4.18 \mathrm{~A}$ & $5.4 \pm 0.72 \mathrm{~B} \mathrm{~b}$ & $12.0 \pm 3.01 \mathrm{~A}$ & $5.2 \pm 0.04 \mathrm{~A} \mathrm{~b}$ & $1.1 \pm 0.17 \mathrm{~A}$ \\
\hline \multirow{4}{*}{$341 / \mathrm{P} 1103$} & 2012 & $21 \pm 1.83 \mathrm{~B} \mathrm{~ns}$ & $4.0 \pm 0.45 \mathrm{C} \mathrm{b}$ & $8.8 \pm 0.63 \mathrm{C} \mathrm{ns}$ & $3.3 \pm 0.54 \mathrm{~B} \mathrm{~ns}$ & $0.5 \pm 0.05 \mathrm{~B} \mathrm{a}$ \\
\hline & 2013 & $24 \pm 5.40 \mathrm{~B}$ & $4.7 \pm 0.21 \mathrm{~B} \mathrm{a}$ & $10.4 \pm 0.79 \mathrm{BC}$ & $3.6 \pm 0.83 \mathrm{~B}$ & $0.2 \pm 0.04 \mathrm{C} \mathrm{b}$ \\
\hline & 2014 & $20 \pm 0.85 \mathrm{~B}$ & $3.9 \pm 0.38 \mathrm{~B} \mathrm{~b}$ & $8.6 \pm 3.90 \mathrm{C}$ & $2.9 \pm 0.74 \mathrm{~B}$ & $0.5 \pm 0.02 \mathrm{~B} \mathrm{a}$ \\
\hline & 2015 & $24 \pm 0.85 \mathrm{~B}$ & $4.7 \pm 0.06 \mathrm{C} \mathrm{a}$ & $10.4 \pm 3.04 \mathrm{BC}$ & $3.2 \pm 0.67 \mathrm{~B}$ & $0.3 \pm 0.09 \mathrm{C} \mathrm{ab}$ \\
\hline \multirow{4}{*}{ R5/P1103 } & 2012 & $27 \pm 1.44 \mathrm{~B} \mathrm{~ns}$ & $5.2 \pm 0.45 \mathrm{C} \mathrm{a}$ & $11.5 \pm 1.46 \mathrm{BC}$ ns & $4.0 \pm 0.22 \mathrm{~B} \mathrm{a}$ & $0.7 \pm 0.04 \mathrm{~B} \mathrm{~ns}$ \\
\hline & 2013 & $26 \pm 4.72 \mathrm{~B}$ & $5.0 \pm 0.28 \mathrm{~B} \mathrm{a}$ & $11.1 \pm 0.83 \mathrm{~B}$ & $3.2 \pm 0.84 \mathrm{~B} \mathrm{bc}$ & $0.6 \pm 0.21 \mathrm{~B}$ \\
\hline & 2014 & $23 \pm 2.35 \mathrm{~B}$ & $4.4 \pm 0.37 \mathrm{~B} \mathrm{~b}$ & $9.7 \pm 1.52 \mathrm{C}$ & $3.0 \pm 0.37 \mathrm{~B} \mathrm{c}$ & $0.5 \pm 0.19 \mathrm{~B}$ \\
\hline & 2015 & $19 \pm 3.71 \mathrm{C}$ & $3.6 \pm 0.46 \mathrm{D} \mathrm{b}$ & $8.0 \pm 1.86 \mathrm{C}$ & $2.8 \pm 0.21 \mathrm{~B} \mathrm{c}$ & $0.7 \pm 0.08 \mathrm{~B}$ \\
\hline \multirow{4}{*}{ 169/C3309 } & 2012 & $25 \pm 2.40 \mathrm{~B} \mathrm{~ns}$ & $4.9 \pm 0.44 \mathrm{C} \mathrm{b}$ & $10.8 \pm 0.05 \mathrm{C} \mathrm{ns}$ & $1.63 \pm 0.69 \mathrm{C} \mathrm{c}$ & $1.0 \pm 0.07 \mathrm{~A} \mathrm{a}$ \\
\hline & 2013 & $28 \pm 2.49 \mathrm{~B}$ & $5.4 \pm 0.25 \mathrm{~B} \mathrm{a}$ & $12.0 \pm 0.06 \mathrm{~A}$ & $1.96 \pm 0.71 \mathrm{C} \mathrm{bc}$ & $0.5 \pm 0.05 \mathrm{~B} \mathrm{c}$ \\
\hline & 2014 & $29 \pm 1.25 \mathrm{AB}$ & $5.6 \pm 0.71 \mathrm{~A} \mathrm{a}$ & $12.4 \pm 0.77 \mathrm{~A}$ & $2.57 \pm 0.55 \mathrm{~B} \mathrm{a}$ & $0.7 \pm 0.08 \mathrm{~B} \mathrm{~b}$ \\
\hline & 2015 & $22 \pm 0.17 \mathrm{~B}$ & $4.2 \pm 0.14 \mathrm{D} \mathrm{b}$ & $9.3 \pm 1.26 \mathrm{C}$ & $2.41 \pm 0.48 \mathrm{~B} \mathrm{a}$ & $0.9 \pm 0.14 \mathrm{~B} \mathrm{ab}$ \\
\hline \multirow{4}{*}{ 170/C3309 } & 2012 & $26 \pm 2.04 \mathrm{~B} \mathrm{~ns}$ & $6.0 \pm 0.38 \mathrm{~B} \mathrm{a}$ & $13.3 \pm 0.58 \mathrm{~B} \mathrm{a}$ & $3.9 \pm 0.28 \mathrm{~B} \mathrm{a}$ & $0.4 \pm 0.16 \mathrm{~B} \mathrm{~b}$ \\
\hline & 2013 & $28 \pm 2.49 \mathrm{~B}$ & $5.4 \pm 0.56 \mathrm{~B} \mathrm{~b}$ & $12.0 \pm 0.82 \mathrm{~A} \mathrm{a}$ & $3.5 \pm 0.54 \mathrm{~B} \mathrm{a}$ & $0.4 \pm 0.11 \mathrm{~B} \mathrm{~b}$ \\
\hline & 2014 & $25 \pm 1.94 \mathrm{~B}$ & $4.9 \pm 0.05 \mathrm{~B} \mathrm{~b}$ & $10.8 \pm 0.55 \mathrm{BC} \mathrm{a}$ & $3.0 \pm 0.86 \mathrm{~B} \mathrm{~b}$ & $0.6 \pm 0.08 \mathrm{~B} \mathrm{a}$ \\
\hline & 2015 & $23 \pm 2.76 \mathrm{~B}$ & $4.4 \pm 0.33 \mathrm{D} \mathrm{c}$ & $9.7 \pm 0.72 \mathrm{C} \mathrm{b}$ & $2.8 \pm 0.43 \mathrm{~B} \mathrm{~b}$ & $0.8 \pm 0.05 \mathrm{~B} \mathrm{a}$ \\
\hline \multirow{4}{*}{ 339/C3309 } & 2012 & $39 \pm 2.33 \mathrm{~A} \mathrm{~ns}$ & $7.6 \pm 0.53 \mathrm{~A} \mathrm{a}$ & $16.8 \pm 1.18 \mathrm{~A} \mathrm{~ns}$ & $4.7 \pm 0.80 \mathrm{Ac}$ & $1.2 \pm 0.03 \mathrm{~A} \mathrm{~ns}$ \\
\hline & 2013 & $36 \pm 2.49 \mathrm{~A}$ & $6.6 \pm 0.23 \mathrm{~A} \mathrm{~b}$ & $14.6 \pm 2.46 \mathrm{~A}$ & $5.3 \pm 0.09 \mathrm{Ab}$ & $1.3 \pm 0.06 \mathrm{~A}$ \\
\hline & 2014 & $31 \pm 1.25 \mathrm{~A}$ & $6.0 \pm 0.12 \mathrm{Ac}$ & $13.3 \pm 1.89 \mathrm{~A}$ & $5.7 \pm 0.80 \mathrm{~A} \mathrm{a}$ & $1.4 \pm 0.08 \mathrm{~A}$ \\
\hline & 2015 & $34 \pm 2.72 \mathrm{~A}$ & $6.4 \pm 0.21 \mathrm{~A} \mathrm{bc}$ & $14.2 \pm 2.31 \mathrm{~A}$ & $5.8 \pm 0.09 \mathrm{~A} \mathrm{a}$ & $1.2 \pm 0.16 \mathrm{~A}$ \\
\hline
\end{tabular}

Data are the mean of each year \pm standard deviation; the means values followed by the same uppercase in the columm among combinations and years and by the same lowercase among years for each productivity parameter do not differ among themselves as identified by Tukey test $(\mathrm{p} \leq 0.05) ;{ }^{*} \mathrm{~ns}=$ indicate not significant for analysis of variance $($ ANOVA $)(\mathrm{p} \leq 0.05)$ 
Table 2- Physical parameters of different combinations of 'Cabernet Sauvignon' clones 169, 337, 341 and R5 grafted onto 'Paulsen 1103' (P1103) rootstock and clones 169, 170 and 339 grafted onto 'Courdec 3309' (C3309), during the 2012, 2013, 2014 and 2015 growing season. São Joaquim, Santa Catarina State, Brazil, 2019.

\begin{tabular}{|c|c|c|c|c|c|c|c|}
\hline \multirow[b]{2}{*}{ Combination } & \multirow[b]{2}{*}{ Season } & \multicolumn{6}{|c|}{ Physical parameters } \\
\hline & & Cluster mass (g) & $\begin{array}{l}\text { Berries per } \\
\text { cluster }\end{array}$ & $\begin{array}{l}\text { Compactness } \\
\text { index }\end{array}$ & $\begin{array}{l}\text { Berries diameter } \\
\qquad(\mathrm{cm})\end{array}$ & $\begin{array}{l}100 \text { berries } \\
\text { mass }(\mathrm{g})\end{array}$ & $\begin{array}{l}\text { Skin:berry } \\
\text { ratio }(\%)\end{array}$ \\
\hline \multirow{4}{*}{ 169/P1103 } & 2012 & $120.4 \pm 15.40 \mathrm{~B} \mathrm{a}$ & $80.0 \pm 7.52 \mathrm{C} \mathrm{a}$ & $5.6 \pm 0.25 \mathrm{~B} \mathrm{~b}$ & $1.36 \pm 0.03 \mathrm{~ns}$ & $156.3 \pm 3.07 \mathrm{~A} \mathrm{ab}$ & $31.5 \pm 3.68 \mathrm{~A} \mathrm{~ns}$ \\
\hline & 2013 & $122.4 \pm 13.54 \mathrm{~B} \mathrm{a}$ & $86.3 \pm 6.52 \mathrm{~B} \mathrm{a}$ & $6.8 \pm 0.21 \mathrm{~B} \mathrm{a}$ & $1.42 \pm 0.03$ & $171.0 \pm 0.61 \mathrm{~A} \mathrm{a}$ & $37.2 \pm 4.57 \mathrm{~A}$ \\
\hline & 2014 & $95.2 \pm 13.01 \mathrm{~A} \mathrm{~b}$ & $52.7 \pm 8.69 \mathrm{~B} \mathrm{c}$ & $4.7 \pm 0.25 \mathrm{~ns}^{*} \mathrm{c}$ & $1.33 \pm 0.03$ & $166.5 \pm 7.60 \mathrm{~A} \mathrm{ab}$ & $28.7 \pm 3.91 \mathrm{~A}$ \\
\hline & 2015 & $119.7 \pm 14.37 \mathrm{C} \mathrm{a}$ & $76.5 \pm 6.73 \mathrm{Cb}$ & $6.2 \pm 0.40 \mathrm{~B} \mathrm{a}$ & $1.40 \pm 0.04$ & $147.2 \pm 1.76 \mathrm{~A} \mathrm{~b}$ & $34.2 \pm 4.57 \mathrm{~A}$ \\
\hline \multirow{4}{*}{ 337/P1103 } & 2012 & $148.0 \pm 13.92 \mathrm{~A} \mathrm{a}$ & $97.0 \pm 7.88 \mathrm{~A} \mathrm{a}$ & $6.4 \pm 0.45 \mathrm{~A} \mathrm{~b}$ & $1.35 \pm 0.02$ & $156.5 \pm 5.78 \mathrm{~A} \mathrm{~b}$ & $33.8 \pm 3.84 \mathrm{~A}$ \\
\hline & 2013 & $151.1 \pm 11.93 \mathrm{~A} \mathrm{a}$ & $99.8 \pm 7.04 \mathrm{~A} \mathrm{a}$ & $7.9 \pm 0.14 \mathrm{~A} \mathrm{a}$ & $1.41 \pm 0.03$ & $167.9 \pm 5.79 \mathrm{~A} \mathrm{a}$ & $39.1 \pm 2.88 \mathrm{~A}$ \\
\hline & 2014 & $85.7 \pm 14.14 \mathrm{~A} \mathrm{~b}$ & $65.3 \pm 8.22 \mathrm{~A} \mathrm{~b}$ & $4.8 \pm 0.48 \quad \mathrm{c}$ & $1.37 \pm 0.02$ & $173.9 \pm 3.53 \mathrm{~A} \mathrm{a}$ & $32.4 \pm 3.02 \mathrm{~A}$ \\
\hline & 2015 & $150.7 \pm 13.01 \mathrm{~A} \mathrm{a}$ & $105.4 \pm 7.76 \mathrm{~A} \mathrm{a}$ & $7.6 \pm 0.84 \mathrm{~A} \mathrm{a}$ & $1.39 \pm 0.03$ & $137.9 \pm 7.31 \mathrm{~B} \mathrm{c}$ & $37.1 \pm 2.88 \mathrm{~A}$ \\
\hline \multirow{4}{*}{ 341/P1103 } & 2012 & $122.0 \pm 13.92 \mathrm{C} \mathrm{a}$ & $87.7 \pm 11.38 \mathrm{~B} \mathrm{a}$ & $5.5 \pm 0.29 \mathrm{~B} \mathrm{a}$ & $1.36 \pm 0.03$ & $157.7 \pm 6.46 \mathrm{~A} \mathrm{a}$ & $33.7 \pm 5.43 \mathrm{~A}$ \\
\hline & 2013 & $117.8 \pm 9.97 \mathrm{BC} \mathrm{a}$ & $81.2 \pm 10.33 \mathrm{~B} \mathrm{a}$ & $6.1 \pm 0.62 \mathrm{~B} \mathrm{a}$ & $1.35 \pm 0.04$ & $168.4 \pm 9.42 \mathrm{~A} \mathrm{a}$ & $35.4 \pm 5.20 \mathrm{~A}$ \\
\hline & 2014 & $64.0 \pm 11.42 \mathrm{BC} \mathrm{b}$ & $55.3 \pm 11.08 \mathrm{~B} \mathrm{~b}$ & $4.5 \pm 0.24 \quad b$ & $1.34 \pm 0.03$ & $158.3 \pm 1.21 \mathrm{AB} a$ & $30.6 \pm 4.96 \mathrm{~A}$ \\
\hline & 2015 & $119.8 \pm 12.01 \mathrm{C} \mathrm{a}$ & $85.3 \pm 9.45 \mathrm{~B} \mathrm{a}$ & $5.9 \pm 0.51 \mathrm{~B} \mathrm{a}$ & $1.40 \pm 0.04$ & $151.1 \pm 7.09 \mathrm{~A} \mathrm{~b}$ & $32.4 \pm 5.20 \mathrm{~A}$ \\
\hline \multirow{4}{*}{ R5/P1103 } & 2012 & $131.7 \pm 13.75 \mathrm{~B} \mathrm{a}$ & $92.2 \pm 7.78 \mathrm{~B} \mathrm{a}$ & $5.7 \pm 0.30 \mathrm{~B} \mathrm{~b}$ & $1.35 \pm 0.03$ & $149.6 \pm 5.67 \mathrm{~A} \mathrm{~b}$ & $28.3 \pm 5.10 \mathrm{~A}$ \\
\hline & 2013 & $132.1 \pm 11.59 \mathrm{~B} \mathrm{a}$ & $87.2 \pm 7.81 \mathrm{~B} \mathrm{a}$ & $6.7 \pm 0.44 \mathrm{~B}$ a & $1.38 \pm 0.04$ & $135.3 \pm 8.16 \mathrm{~B} \mathrm{a}$ & $34.3 \pm 3.58 \mathrm{~A}$ \\
\hline & 2014 & $92.5 \pm 15.24 \mathrm{~A} \mathrm{~b}$ & $51.9 \pm 6.95 \mathrm{~B} \mathrm{~b}$ & $4.9 \pm 0.26 \quad \mathrm{c}$ & $1.32 \pm 0.02$ & $158.6 \pm 2.91 \mathrm{~A} \mathrm{a}$ & $32.1 \pm 4.46 \mathrm{~A}$ \\
\hline & 2015 & $129.7 \pm 12.66 \mathrm{~B} \mathrm{a}$ & $94.0 \pm 7.33 \mathrm{~B} \mathrm{a}$ & $6.0 \pm 0.30 \mathrm{~B} \mathrm{a}$ & $1.34 \pm 0.04$ & $140.1 \pm 5.13 \mathrm{~B} \mathrm{~b}$ & $31.3 \pm 3.58 \mathrm{~A}$ \\
\hline \multirow{4}{*}{ 169/C3309 } & 2012 & $104.2 \pm 13.78 \mathrm{D} \mathrm{a}$ & $78.5 \pm 7.40 \mathrm{~b} \mathrm{a}$ & $7.0 \pm 0.46 \mathrm{~A} \mathrm{a}$ & $1.31 \pm 0.05$ & $123.7 \pm 7.94 \mathrm{C} \mathrm{b}$ & $21.2 \pm 5.77 \mathrm{~B}$ \\
\hline & 2013 & $103.1 \pm 14.21 \mathrm{C} \mathrm{a}$ & $72.5 \pm 8.15 \mathrm{~B} \mathrm{a}$ & $6.8 \pm 0.72 \mathrm{~B} \mathrm{a}$ & $1.36 \pm 0.03$ & $147.9 \pm 2.33 \mathrm{~B} \mathrm{a}$ & $22.3 \pm 3.68 \mathrm{~B}$ \\
\hline & 2014 & $71.8 \pm 11.59 \mathrm{~B} \mathrm{~b}$ & $45.9 \pm 8.03 \mathrm{~B} \mathrm{~b}$ & $4.9 \pm 0.10 \quad \mathrm{c}$ & $1.27 \pm 0.04$ & $135.3 \pm 9.70 \mathrm{~B} \mathrm{a}$ & $20.9 \pm 8.37 \mathrm{~B}$ \\
\hline & 2015 & $109.2 \pm 13.51 \mathrm{C} \mathrm{a}$ & $81.0 \pm 7.86 \mathrm{~B} \mathrm{a}$ & $6.0 \pm 0.35 \mathrm{~B} \mathrm{~b}$ & $1.30 \pm 0.01$ & $102.0 \pm 11.17 \mathrm{C} \mathrm{c}$ & $21.1 \pm 3.68 \mathrm{~B}$ \\
\hline \multirow{4}{*}{ 170/C3309 } & 2012 & $130.3 \pm 14.58 \mathrm{~B} \mathrm{a}$ & $92.5 \pm 7.04 \mathrm{~B} \mathrm{a}$ & $6.9 \pm 0.86 \mathrm{~B} \mathrm{a}$ & $1.33 \pm 0.11$ & $147.1 \pm 5.87 \mathrm{~A} \mathrm{~b}$ & $33.83 \pm 4.95 \mathrm{~A}$ \\
\hline & 2013 & $125.5 \pm 13.09 \mathrm{~B} \mathrm{a}$ & $85.1 \pm 7.71 \mathrm{~B} \mathrm{a}$ & $6.6 \pm 0.49 \mathrm{~B} \mathrm{a}$ & $1.27 \pm 0.04$ & $158.0 \pm 6.55 \mathrm{~A} \mathrm{a}$ & $39.2 \pm 3.98 \mathrm{~A}$ \\
\hline & 2014 & $79.3 \pm 14.09 \mathrm{~B} \mathrm{~b}$ & $50.7 \pm 7.32 \mathrm{~B} \mathrm{c}$ & $4.5 \pm 0.38 \quad \mathrm{c}$ & $1.38 \pm 0.11$ & $154.7 \pm 4.13 \mathrm{~B} \mathrm{a}$ & $29.5 \pm 5.71 \mathrm{~A}$ \\
\hline & 2015 & $127.3 \pm 11.68 \mathrm{~B} \mathrm{a}$ & $72.3 \pm 8.16 \mathrm{C} \mathrm{b}$ & $5.9 \pm 0.55 \mathrm{~B} \mathrm{~b}$ & $1.27 \pm 0.04$ & $131.2 \pm 5.68 \mathrm{~B} \mathrm{c}$ & $33.2 \pm 3.98 \mathrm{~A}$ \\
\hline \multirow{4}{*}{ 339/C3309 } & 2012 & $139.2 \pm 12.32 \mathrm{AB}$ a & $105.9 \pm 10.33 \mathrm{~A} \mathrm{a}$ & $7.6 \pm 0.53 \mathrm{~A} \mathrm{a}$ & $1.34 \pm 0.18$ & $146.6 \pm 7.21 \mathrm{~B} \mathrm{~b}$ & $32.70 \pm 4.67 \mathrm{~A}$ \\
\hline & 2013 & $156.7 \pm 17.32 \mathrm{~A} \mathrm{a}$ & $102.11 \pm 9.21 \mathrm{~A} \mathrm{a}$ & $7.8 \pm 0.42 \mathrm{~A} \mathrm{a}$ & $1.36 \pm 0.01$ & $159.3 \pm 6.80 \mathrm{~A} \mathrm{a}$ & $34.7 \pm 4.46 \mathrm{~A}$ \\
\hline & 2014 & $83.5 \pm 15.37 \mathrm{~A} \mathrm{~b}$ & $68.9 \pm 9.89 \mathrm{~A} \mathrm{~b}$ & $4.7 \pm 0.23 b$ & $1.39 \pm 0.01$ & $154.6 \pm 9.94 \mathrm{~B} \mathrm{ab}$ & $29.5 \pm 6.41 \mathrm{~A}$ \\
\hline & 2015 & $136.1 \pm 11.08 \mathrm{~B} \mathrm{a}$ & $99.5 \pm 10.07 \mathrm{~A} \mathrm{a}$ & $7.9 \pm 0.37 \mathrm{~A} \mathrm{a}$ & $1.40 \pm 0.01$ & $157.3 \pm 5.37 \mathrm{~A} \mathrm{a}$ & $37.7 \pm 4.46 \mathrm{~A}$ \\
\hline
\end{tabular}

Data are the mean of each year \pm standard deviation; the means values followed by the same uppercase in the columm among combinations and years and by the same lowercase among years for each physical parameter do not differ among themselves as identified by Tukey test ( $\mathrm{p}$ $\leq 0.05) ;{ }^{*} \mathrm{~ns}=$ indicate not significant for analysis of variance $($ ANOVA) $(\mathrm{p} \leq 0.05)$ 
Table 3- Chemical parameters of different combinations of 'Cabernet Sauvignon' clones 169, 337, 341 and R5 grafted onto 'Paulsen 1103' (P1103) rootstock and clones 169, 170 and 339 grafted onto 'Courdec 3309' (C3309), during the 2012, 2013, 2014 and 2015 growing season. São Joaquim, Santa Catarina State, Brazil, 2019.

\begin{tabular}{|c|c|c|c|c|}
\hline \multirow{2}{*}{ Combination } & \multirow[b]{2}{*}{ Season } & \multicolumn{3}{|c|}{ Chemical parameters } \\
\hline & & Soluble solids ( $\left.{ }^{\circ} \mathrm{Brix}\right)$ & Total acidity $\left(\right.$ meq L $\left.{ }^{-1}\right)$ & $\mathrm{pH}$ \\
\hline \multirow{4}{*}{ 169/P1103 } & 2012 & $19.1 \pm 0.42 \mathrm{~B} \mathrm{~ns}$ & $161.9 \pm 10.07 \mathrm{Ans}$ & $3.03 \pm 0.09 \mathrm{~A} \mathrm{~b}$ \\
\hline & 2013 & $19.0 \pm 0.05 \mathrm{~B}$ & $156.1 \pm 9.77 \mathrm{~A}$ & $3.07 \pm 0.04 \mathrm{Ab}$ \\
\hline & 2014 & $19.2 \pm 0.65 \mathrm{~B}$ & $158.1 \pm 2.96 \mathrm{~A}$ & $3.15 \pm 0.07 \mathrm{~A} \mathrm{a}$ \\
\hline & 2015 & $18.5 \pm 0.34 \mathrm{~B}$ & $153.5 \pm 15.30 \mathrm{~B}$ & $3.17 \pm 0.02 \mathrm{~A} \mathrm{a}$ \\
\hline \multirow{4}{*}{ 337/P1103 } & 2012 & $19.2 \pm 0.43 \mathrm{~B} \mathrm{~ns}$ & $164.4 \pm 15.84 \mathrm{~A} \mathrm{~ns}$ & $3.08 \pm 0.07 \mathrm{~A} \mathrm{~b}$ \\
\hline & 2013 & $19.3 \pm 0.76 \mathrm{~B}$ & $161.9 \pm 18.75 \mathrm{~A}$ & $2.99 \pm 0.09 \mathrm{~B} \mathrm{~b}$ \\
\hline & 2014 & $19.7 \pm 0.21 \mathrm{~B}$ & $164.3 \pm 16.89 \mathrm{~A}$ & $3.05 \pm 0.10 \mathrm{Ab}$ \\
\hline & 2015 & $19.8 \pm 0.42 \mathrm{~A}$ & $167.3 \pm 11.54 \mathrm{~A}$ & $3.21 \pm 0.04 \mathrm{~A} \mathrm{a}$ \\
\hline \multirow{4}{*}{ 341/P1103 } & 2012 & $19.7 \pm 0.26 \mathrm{~B} \mathrm{~ns}$ & $164.5 \pm 16.45 \mathrm{~A} \mathrm{~ns}$ & $3.07 \pm 0.04 \mathrm{Ab}$ \\
\hline & 2013 & $19.1 \pm 0.31 \mathrm{~B}$ & $161.3 \pm 21.27 \mathrm{~A}$ & $3.04 \pm 0.07 \mathrm{~A} \mathrm{~b}$ \\
\hline & 2014 & $19.2 \pm 0.15 \mathrm{~B}$ & $157.1 \pm 13.40 \mathrm{~A}$ & $3.13 \pm 0.03 \mathrm{~A} \mathrm{a}$ \\
\hline & 2015 & $20.0 \pm 0.32 \mathrm{~A}$ & $167.8 \pm 14.27 \mathrm{~A}$ & $3.19 \pm 0.02 \mathrm{~A} \mathrm{a}$ \\
\hline \multirow{4}{*}{$\mathrm{R} 5 / \mathrm{P} 1103$} & 2012 & $21.7 \pm 0.25 \mathrm{~A} \mathrm{~ns}$ & $140.05 \pm 13.32 \mathrm{~B} \mathrm{~ns}$ & $2.91 \pm 0.14 \mathrm{~B} \mathrm{~ns}$ \\
\hline & 2013 & $21.8 \pm 0.21 \mathrm{~A}$ & $136.6 \pm 3.04 \mathrm{C}$ & $2.77 \pm 0.37 \mathrm{C}$ \\
\hline & 2014 & $20.7 \pm 0.26 \mathrm{~A}$ & $139.0 \pm 11.33 \mathrm{~B}$ & $2.93 \pm 0.05 \mathrm{~B}$ \\
\hline & 2015 & $20.6 \pm 0.28 \mathrm{~A}$ & $142.9 \pm 18.72 \mathrm{BC}$ & $2.85 \pm 0.06 \mathrm{C}$ \\
\hline \multirow{4}{*}{ 169/C3309 } & 2012 & $21.9 \pm 0.15 \mathrm{~A} \mathrm{a}$ & $135.1 \pm 12.84 \mathrm{~B} \mathrm{~ns}$ & $2.72 \pm 0.15 \mathrm{~B} \mathrm{~ns}$ \\
\hline & 2013 & $20.4 \pm 0.06 \mathrm{~A} \mathrm{~b}$ & $131.8 \pm 8.29 \mathrm{C}$ & $2.92 \pm 0.01 \mathrm{~B}$ \\
\hline & 2014 & $20.7 \pm 0.05 \mathrm{Ab}$ & $131.9 \pm 10.7 \mathrm{~B}$ & $2.87 \pm 0.04 \mathrm{~B}$ \\
\hline & 2015 & $21.1 \pm 0.40 \mathrm{~A} \mathrm{ab}$ & $135.1 \pm 12.87 \mathrm{C}$ & $2.83 \pm 0.03 \mathrm{~B}$ \\
\hline \multirow{4}{*}{ 170/C3309 } & 2012 & $20.7 \pm 0.27 \mathrm{~A} \mathrm{~ns}$ & $142.8 \pm 10.66 \mathrm{~B} \mathrm{~b}$ & $2.95 \pm 0.03 \mathrm{~B} \mathrm{a}$ \\
\hline & 2013 & $21.3 \pm 0.15 \mathrm{~A}$ & $142.1 \pm 8.04 \mathrm{Cb}$ & $2.98 \pm 0.03 \mathrm{~B} \mathrm{a}$ \\
\hline & 2014 & $21.6 \pm 0.15 \mathrm{~A}$ & $135.4 \pm 11.11 \mathrm{~B} \mathrm{~b}$ & $2.93 \pm 0.08 \mathrm{~B} \mathrm{a}$ \\
\hline & 2015 & $20.9 \pm 0.44 \mathrm{~A}$ & $152.3 \pm 13.46 \mathrm{~B} \mathrm{a}$ & $2.86 \pm 0.03 \mathrm{BC} \mathrm{b}$ \\
\hline \multirow{4}{*}{ 339/C3309 } & 2012 & $19.3 \pm 0.32 \mathrm{~B} \mathrm{~ns}$ & $156.8 \pm 9.24 \mathrm{~A} \mathrm{a}$ & $3.10 \pm 0.32 \mathrm{~A} \mathrm{a}$ \\
\hline & 2013 & $19.2 \pm 0.05 \mathrm{~B}$ & $152.6 \pm 0.00 \mathrm{BC} \mathrm{a}$ & $3.11 \pm 0.02 \mathrm{~A} \mathrm{a}$ \\
\hline & 2014 & $19.4 \pm 0.59 \mathrm{~B}$ & $148.4 \pm 14.95 \mathrm{~A} \mathrm{a}$ & $3.06 \pm 0.07 \mathrm{~A} \mathrm{~b}$ \\
\hline & 2015 & $20.1 \pm 0.29 \mathrm{~A}$ & $143.8 \pm 8.89 \mathrm{BC} \mathrm{b}$ & $3.18 \pm 0.04 \mathrm{~A} \mathrm{a}$ \\
\hline
\end{tabular}

Data are the mean of each year \pm standard deviation; the means values followed by the same uppercase in the columm among combinations and years and by the same lowercase among years for each chemical parameter do not differ among themselves as identified by Tukey test ( $\mathrm{p}$ $\leq 0.05) ;{ }^{*} \mathrm{~ns}=$ indicate not significant for analysis of variance $(\mathrm{ANOVA})(\mathrm{p} \leq 0.05)$ 
Table 4- Polyphenols and color parameters of different combinations of 'Cabernet Sauvignon' clones 169, 337, 341 and R5 grafted onto 'Paulsen 1103' (P1103) rootstock and clones 69, 170 and 339 grafted onto 'Courdec 3309' (C3309), during the 2012, 2013, 2014 and 2015 growing season. São Joaquim, Santa Catarina State, Brazil, 2019.

\begin{tabular}{|c|c|c|c|c|c|}
\hline \multirow[b]{2}{*}{ Combination } & \multirow[b]{2}{*}{ Season } & \multicolumn{4}{|c|}{ Polyphenols and color parameters } \\
\hline & & $\begin{array}{l}\text { Total polyphenols } \\
\qquad\left(\mathrm{mg} \mathrm{L}^{-1}\right)\end{array}$ & Anthocyanin $\left(\mathrm{mg} \mathrm{L}^{-1}\right)$ & $\begin{array}{c}\text { Berry color, } \\
\text { intensity } \\
(420+520+620 \\
\mathrm{nm})\end{array}$ & $\begin{array}{c}\text { Berry color, hue } \\
(420 / 520 \mathrm{~nm})\end{array}$ \\
\hline \multirow{4}{*}{ 169/P1103 } & 2012 & $1,607.5 \pm 216.3 \mathrm{~B} \mathrm{a}$ & $1,104.77 \pm 111.8 \mathrm{~B} \mathrm{a}$ & $8.53 \pm 0.87 \mathrm{~B}$ bc & $1.06 \pm 0.19 \mathrm{~B} \mathrm{~ns}$ \\
\hline & 2013 & $1,458.7 \pm 123.93 \mathrm{~ns} \mathrm{~b}$ & $898.4 \pm 64.72 \mathrm{~B} \mathrm{~b}$ & $7.28 \pm 0.30 \mathrm{Cc}$ & $0.96 \pm 0.01 \mathrm{~B}$ \\
\hline & 2014 & $1,798.3 \pm 371.16 \mathrm{D} \mathrm{a}$ & $1,149.3 \pm 103.02 \mathrm{~B} \mathrm{a}$ & $9.24 \pm 1.16 \mathrm{~B} \mathrm{a}$ & $0.90 \pm 0.02 \mathrm{~B}$ \\
\hline & 2015 & $1,400.8 \pm 255.10 \mathrm{C} \mathrm{b}$ & $1,040.8 \pm 174.02 \mathrm{~B} \mathrm{a}$ & $9.60 \pm 0.54 \mathrm{~B} \mathrm{a}$ & $1.09 \pm 0.41 \mathrm{~B}$ \\
\hline \multirow{4}{*}{$337 / \mathrm{P} 1103$} & 2012 & $2,207.9 \pm 75.50 \mathrm{Ab}$ & $1,056.7 \pm 88.82 \mathrm{~B} \mathrm{a}$ & $8.78 \pm 0.87 \mathrm{~B} \mathrm{~ns}$ & $1.03 \pm 0.07 \mathrm{~B} \mathrm{a}$ \\
\hline & 2013 & $1,603.3 \pm 65.63 \mathrm{c}$ & $860.2 \pm 23.63 \mathrm{~B} \mathrm{~b}$ & $8.58 \pm 0.41 \mathrm{~B}$ & $1.09 \pm 0.04 \mathrm{~B} \mathrm{a}$ \\
\hline & 2014 & $3,859.6 \pm 63.20 \mathrm{~B} \mathrm{a}$ & $1,210.47 \pm 60.64 \mathrm{~B} \mathrm{a}$ & $8.25 \pm 0.66 \mathrm{~B}$ & $0.89 \pm 0.04 \mathrm{~B} \mathrm{~b}$ \\
\hline & 2015 & $2,254.3 \pm 27.97 \mathrm{~B} \mathrm{~b}$ & $1,226.0 \pm 263.58 \mathrm{~B} \mathrm{a}$ & $9.31 \pm 1.50 \mathrm{~B}$ & $1.08 \pm 0.05 \mathrm{~B} \mathrm{a}$ \\
\hline \multirow{4}{*}{$341 / \mathrm{P} 1103$} & 2012 & $2,113.3 \pm 74.0 \mathrm{AB}$ a & $1,007.77 \pm 89.31 \mathrm{~B} \mathrm{~b}$ & $8.59 \pm 1.76 \mathrm{~B} \mathrm{~b}$ & $1.02 \pm 0.08 \mathrm{C} \mathrm{a}$ \\
\hline & 2013 & $1,537.0 \pm 70.68 \quad b$ & $835.14 \pm 30.58 \mathrm{~B} \mathrm{c}$ & $8.44 \pm 1.14 \mathrm{~B} \mathrm{~b}$ & $1.06 \pm 0.09 \mathrm{~B} \mathrm{a}$ \\
\hline & 2014 & $2,129.3 \pm 343.56 \mathrm{C} \mathrm{a}$ & $1,133.9 \pm 132.01 \mathrm{~B} \mathrm{a}$ & $9.56 \pm 1.52 \mathrm{~B} \mathrm{a}$ & $0.85 \pm 0.03 \mathrm{~B} \mathrm{~b}$ \\
\hline & 2015 & $2,285.4 \pm 431.15 \mathrm{~B} \mathrm{a}$ & $1,021.1 \pm 144.14 \mathrm{~B} \mathrm{a}$ & $9.96 \pm 3.11 \mathrm{~B} \mathrm{a}$ & $0.99 \pm 0.10 \mathrm{C} \mathrm{a}$ \\
\hline \multirow{4}{*}{$\mathrm{R} 5 / \mathrm{P} 1103$} & 2012 & $2,796.3 \pm 79.20 \mathrm{~A} \mathrm{~b}$ & $2,065.2 \pm 56.58 \mathrm{~A} \mathrm{a}$ & $10.89 \pm 1.52 \mathrm{~A} \mathrm{~b}$ & $1.33 \pm 0.10 \mathrm{~A} \mathrm{a}$ \\
\hline & 2013 & $1,600.2 \pm 23.33 \mathrm{c}$ & $1,753.4 \pm 41.67 \mathrm{~A} \mathrm{~b}$ & $9.58 \pm 0.60 \mathrm{Ac}$ & $1.09 \pm 0.04 \mathrm{~A} \mathrm{bc}$ \\
\hline & 2014 & $4,641.4 \pm 49.00 \mathrm{~A} \mathrm{a}$ & $1,624.4 \pm 42.27 \mathrm{~A} \mathrm{bc}$ & $11.4 \pm 0.85 \mathrm{~A} \mathrm{~b}$ & $1.05 \pm 0.12 \mathrm{Ac}$ \\
\hline & 2015 & $2,897.6 \pm 94.41 \mathrm{~A} \mathrm{~b}$ & $1,479.5 \pm 22.34 \mathrm{Ac}$ & $17.60 \pm 3.51 \mathrm{~A} \mathrm{a}$ & $1.12 \pm 0.05 \mathrm{~B} \mathrm{~b}$ \\
\hline \multirow{4}{*}{ 169/C3309 } & 2012 & $2,597.1 \pm 24.3 \mathrm{~A} \mathrm{~b}$ & $1,652,0 \pm 58.30 \mathrm{~A} \mathrm{a}$ & $9.98 \pm 0.54 \mathrm{~A} \mathrm{~b}$ & $1.26 \pm 0.08 \mathrm{~A}$ \\
\hline & 2013 & $1,474.3 \pm 0.03 \quad \mathrm{c}$ & $1,561.9+29.90 \mathrm{~A} \mathrm{a}$ & $9.35 \pm 0.47 \mathrm{~A} \mathrm{~b}$ & $1.35 \pm 0.04 \mathrm{~A}$ \\
\hline & 2014 & $4,947.5 \pm 85.59 \mathrm{~A} \mathrm{a}$ & $1,563.6 \pm 31.96 \mathrm{~A} \mathrm{a}$ & $11.78 \pm 1.05 \mathrm{~A} \mathrm{a}$ & $1.04 \pm 0.04 \mathrm{~A}$ \\
\hline & 2015 & $2,103.18 \pm 22.37 \mathrm{~B} \mathrm{~b}$ & $1,316.6 \pm 45.02 \mathrm{~A} \mathrm{~b}$ & $12.07 \pm 0.48 \mathrm{~A} \mathrm{a}$ & $1.14 \pm 0.12 \mathrm{~A}$ \\
\hline \multirow{4}{*}{ 170/C3309 } & 2012 & $2,524.7 \pm 14.60 \mathrm{Ac}$ & $1,468.2 \pm 57.4 \mathrm{~A} \mathrm{a}$ & $9.96 \pm 1.25 \mathrm{Ac}$ & $1.39 \pm 0.10 \mathrm{~A}$ \\
\hline & 2013 & $1,652.5 \pm 56.20 \mathrm{~d}$ & $1,473.2 \pm 16.19 \mathrm{~A} \mathrm{a}$ & $10.27 \pm 0.39 \mathrm{~A} \mathrm{bc}$ & $1.22 \pm 0.09 \mathrm{~A}$ \\
\hline & 2014 & $4,038.4+41.68 \mathrm{~A} \mathrm{a}$ & $1,384.2 \pm 40.17 \mathrm{~A} \mathrm{a}$ & $10.88 \pm 1.09 \mathrm{~A} \mathrm{a}$ & $1.11 \pm 0.03 \mathrm{~A}$ \\
\hline & 2015 & $3,206.7 \pm 10.32 \mathrm{Ab}$ & $1,268.8 \pm 36.67 \mathrm{~A} \mathrm{~b}$ & $13.59 \pm 3.07 \mathrm{~A} \mathrm{a}$ & $1.30 \pm 0.28 \mathrm{~A}$ \\
\hline \multirow{4}{*}{ 339/C3309 } & 2012 & $2,047.7 \pm 29.4 \mathrm{~B} \mathrm{a}$ & $1,083.4 \pm 46.17 \mathrm{~B} \mathrm{a}$ & $8.69 \pm 0.61 \mathrm{~B} \mathrm{a}$ & $0.88 \pm 0.07 \mathrm{C}$ \\
\hline & 2013 & $1,541.0 \pm 1.00 \mathrm{~b}$ & $866.3 \pm 22.56 \mathrm{~B}$ & $7.85 \pm 0.35 \mathrm{~B} \mathrm{~b}$ & $0.97 \pm 0.04 \mathrm{~B}$ \\
\hline & 2014 & $1,136.9 \pm 68.82 \mathrm{D} \mathrm{c}$ & $1,140.8 \pm 25.77 \mathrm{~B} \mathrm{a}$ & $9.44 \pm 1.32 \mathrm{~B} \mathrm{a}$ & $0.74 \pm 0.03 \mathrm{C}$ \\
\hline & 2015 & $1,139.8 \pm 41.38 \mathrm{C} \mathrm{c}$ & $1,027.4 \pm 30.38 \mathrm{~B} \mathrm{a}$ & $8.64 \pm 2.03 \mathrm{~B} \mathrm{a}$ & $1.06 \pm 0.30$ \\
\hline
\end{tabular}

Data are the mean of each year \pm standard deviation; the means values followed by the same uppercase in the columm among combinations and years and by the same lowercase among years for each Polyphenol and color parameter do not differ among themselves as identified by Tukey test $(\mathrm{p} \leq 0.05) ;{ }^{*} \mathrm{~ns}=$ indicate not significant for analysis of variance (ANOVA) $(\mathrm{p} \leq 0.05)$ 


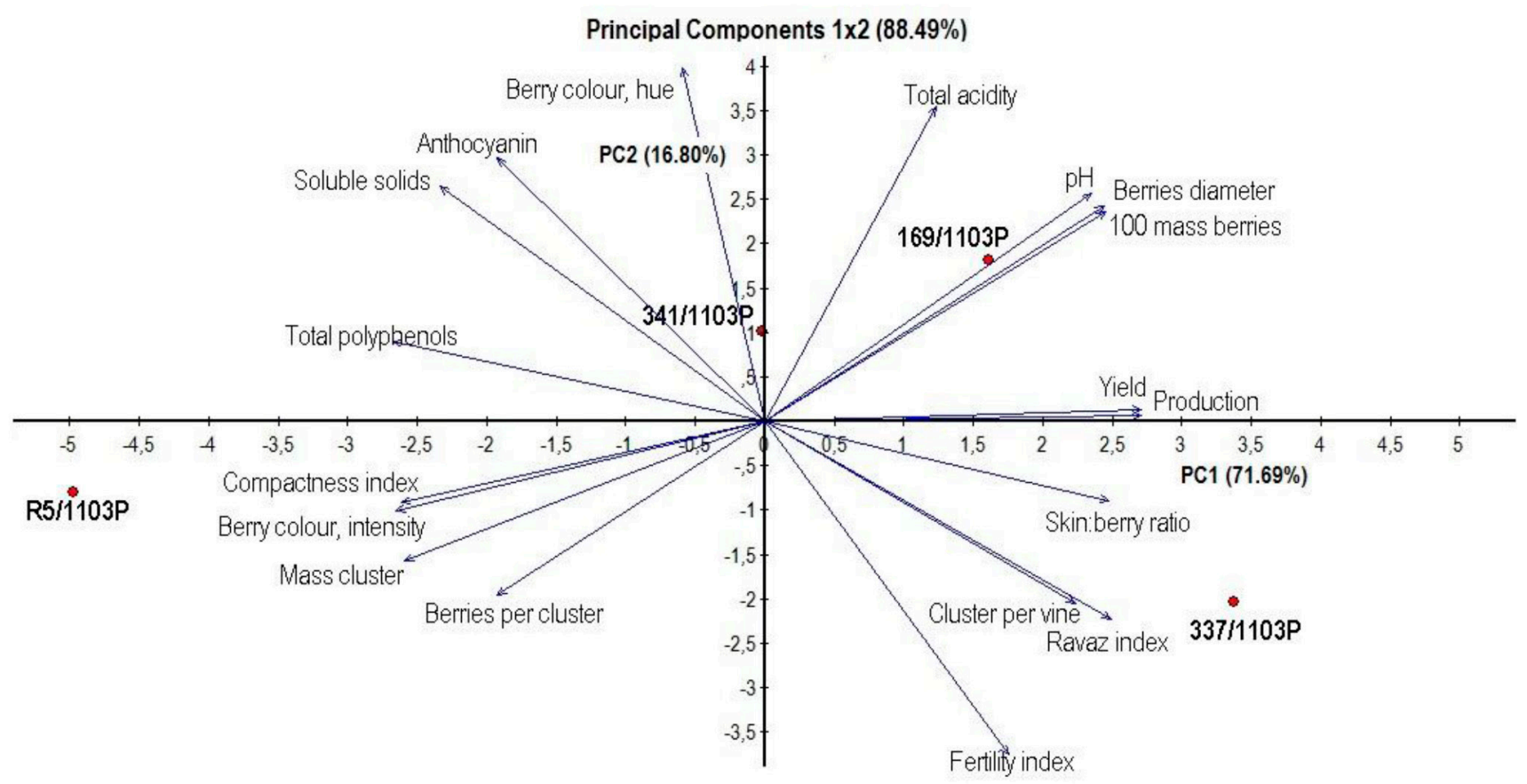

Figure 2- Principal components analysis (PCA) of the significant results from 341, 169, 337 and R5 clones grafted onto rootstock Paulsen 1103 of Cabernet Sauvignon physic-chemical variables, during the 2012, 2013, 2014 and 2015 growing season. São Joaquim, Santa Catarina State, Brazil, 2019.

\section{Principal Components $1 \times 2(100 \%)$}

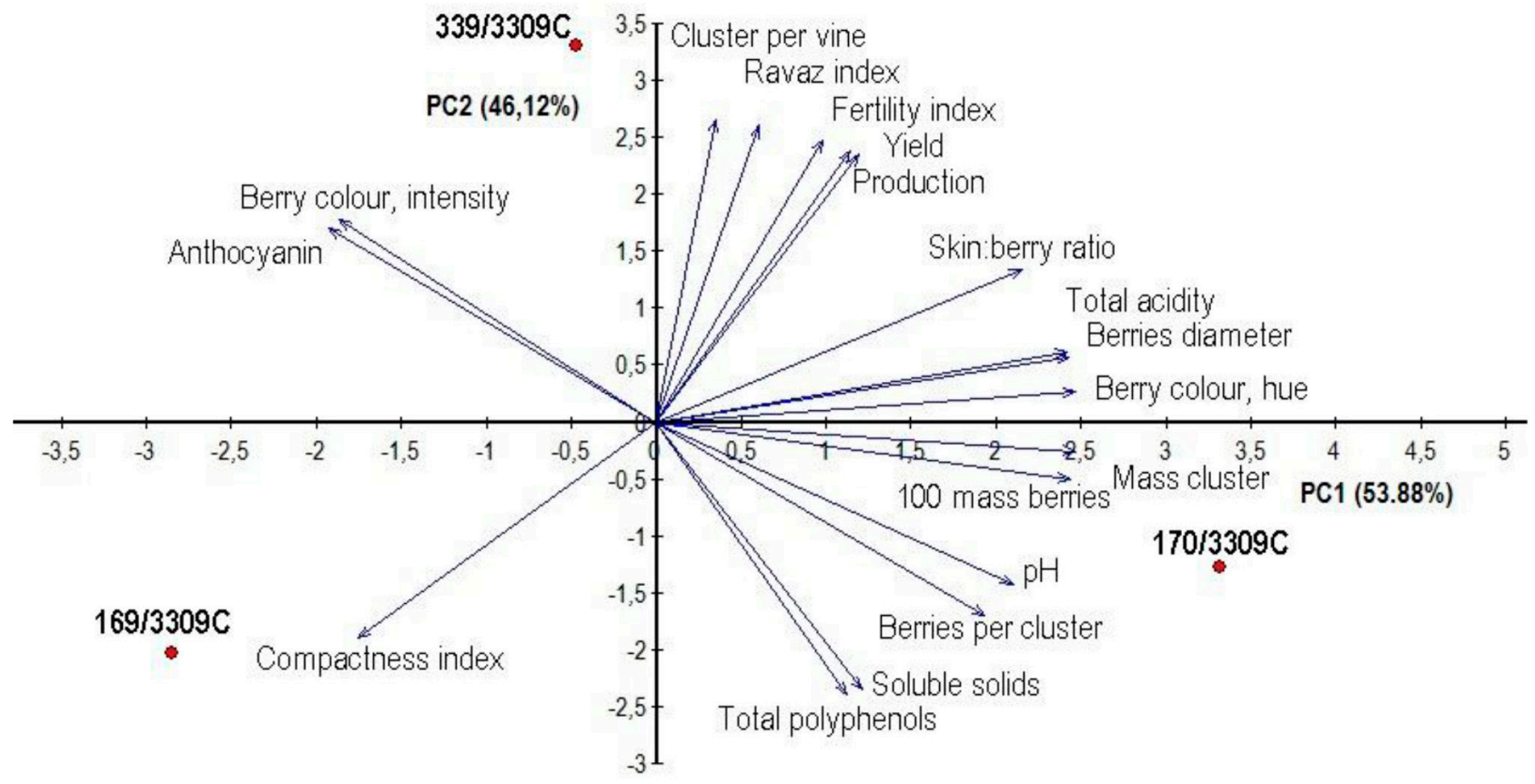

Figure 3- Principal components analysis (PCA) of the significant results from 170, 169 and 339 clones grafted onto rootstock Courdec 3309 of Cabernet Sauvignon physic-chemical variables, during the 2012, 2013, 2014 and 2015 growing season. São Joaquim, Santa Catarina State, Brazil, 2019. 


\section{Conclusions}

Different combinations of the Cabernet Sauvignon clone/rootstock have influenced the physical, chemical, and productivity parameters and maturity of Cabernet Sauvignon grapes produced in the edaphoclimatic conditions of the highlands of Santa Catarina State, southern Brazil, during the 2012-2013, 2013-2014, 2014 2015, and 2015-2016 growing seasons. The Cabernet Sauvignon 339/C3309 and 337/P1103 combinations showed highest yield. The best enological potential was obtained with R5/P1103, 170/C3309, and 169/C3309 combinations.

\section{Acknowledgments}

This research was financially supported by $\mathrm{CNPq}$ (The National Council for Scientific and Technological Development), CAPES (Coordination for the Improvement of Higher Level -or Education- Personnel), FAPESC (Santa Catarina State Foundation for Scientific and Technological Development) and UDESC (Santa Catarina State University).

\section{References}

ALONSO, S.B.; BLANCO, J.L.S.; RODIGUEZ, M.C.M. Intravarietal agronomic variability in Vitis vinifera L. cv. Albariño. American Journal of Enology and Viticulture, Davis, v. 55, p. 279-282, 2004.

ALVARES, C.A.; STAPE, J.L.; SENTELHAS, P.C.; GONÇALVES, J.L. de M.; SPAROVEK. G. Köppen's climate classification map for Brazil. Meteorologische Zeitschrift, Stuttgart, v. 22, n.6, p.711-728, 2013.

BATTISTUTTA, F.; COLUGNATI, G.; BREGANT, F.; CRESPAN, G.; TONETTI, I.; CELOTTI, E.; ZIRONI, $\mathrm{R}$. Influence of genotype on the methoxypyrazines content of Cabernet Sauvignon cultivated in Friuli. Acta Horticulturae, The Hague, v.526, p.407-414, 2000.

BEM, B.P. de; BOGO, A.; EVERHART, S.E.; CASA, R.T.; GONÇALVES, M.J.; MARCON FILHO, J.L.; RUFATO, L.; SILVA, F.N.; ALLEBRANDT, R.; CUNHA, I.C. Effect of four training systems on the temporal dynamics of downy mildew in two grapevine cultivars in southern Brazil. Tropical Plant Pathology, Brasília, DF, v.41, p.370-379, 2016
BORGHEZAN, M. VILLAR, L.; SILVA, T.C.; CANTON, M.; GUERRA, M.P.; CAMPOS, C.G.C. Phenology and vegetative growth in a new production region of grapevine: case study in São Joaquim, Santa Catarina, Southern Brazil. Open Journal of Ecology, Irvine, v.4, p.321-335, 2014.

BORGHEZAN, M.; GAVIOLI, O.; PIT, F.A.; SILVA, A.L. Vegetative and productive behavior of grapevines and composition of grapes in São Joaquim, Santa Catarina, Brazil. Pesquisa Agropecuária Brasileira, Brasília, DF, v.46, p.398-405, 2011.

BRASIL. Ministério da Agricultura, do Abastecimento e da Reforma Agrária. Uva para exportação: aspectos técnicos da produção. Brasília: EMBRAPA-SPI, 2013. (Publicações Técnicas 359, FRUPEX, 25)

BRIGHENTI, A.F.; BRIGHENTI, E.; BONIN, V.; RUFATO, L. Phenological characterization and thermic requirement of distinct grapevines varieties in São Joaquim, Santa Catarina - Brazil - Brasil. Ciência Rural, Santa Maria, v.43, n.7, p.1162-1167, 2013.

BRIGHENTI, A.F.; RUFATO, L.; KRETZSCHMAR, A.A.; MARCON FILHO, J.L.; BRIGHENTI, L.M.; MALINOVSKI, L.I.; SILVA, A.L. Physical-chemical quality of 'Cabernet Sauvignon' clones in high altitude regions of Santa Catarina State, Brazil. Acta Horticulturae, The Hague, v.931, p.385-388, 2012.

BRIGHENTI, A.F.; RUFATO, L.; KRETZSCHMAR, A.A.; SCHLEMPER, C. Viticultural performance of Cabernet Sauvignon grafted on different rootstocks in high altitude regions of the State of Santa Catarina. Revista Brasileira Fruticultura, Jaboticabal, v.33, n.1, p.96102, 2011.

BURIN, V.M.; SILVA, A.L.; MALINOVSKI, L.I.; ROSIER, J.P.; FALCAO, L.D.; BORDIGNON-LUIZ, M. Characterization and multivariate classification of grapes and wines of two Cabernet Sauvignon clones. Pesquisa Agropecuária Brasileira, Brasília, DF, v.46, n.5, p.474481, 2011.

CONDE, C.; SILVA, P.; FONTES, N.; DIAS, A.C.P.; TAVARES, R.M.; SOUSA, M.J.; AGASSE, A.; DELROT, S.; GERÓS, H. Biochemical changes throughout grape berry development and fruit and wine quality. Food, Isleworth v.1, p.1-22, 2007.

DIAS, F.A.N; MOTA, R.V.; SOUZA, C.R.; PIMENTEL, R.M.A.; SOUZA, L.C.; SOUZA, A.L.; REGINA, M.A. Rootstock on vine performance and wine quality of 'Syrah' under double pruning management. Scientia Agricola, Piracicaba, v.74, n.2, p.101-173, 2017 
EPAGRI - Empresa de Pesquisa Agropecuária e Extensão Rural de Santa Catarina Dados climáticos . Florianópolis: Centro de Informações de Recursos Ambientais, 2019. Disponível em: http://ciram.epagri.sc.gov.br. Acesso em: 17 jan. 2019.

FALCÃO, L.D.; CHAVES, E.S.; BURIN, V.M.; FALCÃO, A.P.; GRIS, E.F.; BONIN, V.; BORDIGNON-LUIZ, M.T. Ripening of Cabernet Sauvignon berries from grapevines grown with two different training systems and environmental conditions in a new grape growing region in Brazil. Ciencia e Investigacion Agraria, Santiago, v.35, n.3, p.321 - 332, 2008.

FALLAHI, E.; FALLAHI, B.; SHAFII, B.; STARK, J.C. Performance of six wine grapes under Southwest Idaho environmental conditions. Small Fruits Review, Binghamton, v.4, n.3, p.77-84, 2005.

FERNÁNDEZ-LOPEZ, J.A.; ALMELA, L.; MUNOZ, J. A.; HIDALGO, V.; CARRENO, J. Dependence between colour and individual anthocyanins content in ripening grapes. Food Research International, New York, v.31, n, 3, p.667- 672, 1998.

FIDELIBUS, M.W.; KATAYAMA, DG.; CHRISTENSEN, L.P.; VERDENAL, T. Yield components and Fruit composition of six Cabernet Sauvignon grapevines selections in the Central San Joaquin Valley, California. Journal American of the Pomological Society, State College, v.60, p.25-32, 2006.

GIL, G.; PSZCZOLKOWSKI, P. Viticultura: fundamentos para optimizar producción y calidad. Santiago: Ediciones Universidad Católica de Chile, 2007. 535p.

GIUSTI, M.M.; WROLSTAD, R.E. Anthocyanins. Characterization and measurement with UV-Visible spectroscopy. In: WROLSTAD, R.E. (ed.). Current protocols in food analytical chemistry. New York: John Wiley \& Sons, 2001. p.1- 13.

GÓMEZ-PLAZA, E.; GIL-MUÑOZ, J.; LÓPEZ-ROCA, M.; MARTÍNEZ, A. Color and phenolic compounds of a young red wine. Influence of wine-making techniques, storage temperature, and length of storage time. Journal of Agriculture and Food Chemistry, Washington, v.48, n.3, p.736-741, 2000.

GONZÁLEZ-NEVES, G.; CHARAMELO, D.; BALADO, J.; BARREIRO, L.; BOCHICCHIO, R.; GATTO, G.; TESSORE, A.; CARBONNEAU, M. M. Phenolic potencial of Tannat, Cabernet Sauvignon and Merlot grapes their correspondence with wine composition. Analitica Chimica Acta, Amsterdam, v, 503, n.1, p.191196, 2004.
GONZALEZ-SANJOSE, M.L.; BARRON, L.J.R.; JUNQUERA, B.; ROBREDO, M. Application of principal component analysis to ripening indices for wine grapes. Journal of Food Composition and Analysis, New York, v.4, n.3, p.245 - 255, 1991.

HED, B.; NGUGI, H.K.; TRAVIS, J.W. Relationship between cluster compactness and bunch rot in Vignoles grapes. Plant Disease, Honolulu, v.93, n.11, p.1195-1201, 2009.

JACKSON, D.I.; LOMBARD, P.B. Environmental and management practices affecting grape composition and wine quality - a review. American Journal of Enology and Viticulture, Davis, v.44, n.4, p.409 - 430, 1993.

JACKSON, R. S. Wine science: principles and applications. $4^{\text {th }}$ ed. Amsterdam: Elsevier, 2014. 751p.

LECAS, M.; BRILLOUET, J.M. Cell wall composition of grape berry skins. Phytochemistry, New York, v.35, n.5, p.1241-1243, 1994.

MAFRA, S. H. M.; CASSOL, P.C.; MIQUELUTTI, D.J.; ERNANI, P.R.; GATIBONI, L.C.; FERREIRA, E.Z.; BARROS, M.; ZALAMENA, J.; GROHSKOPF, M.A. Soil chemical attributes and nutrition state of Cabernet Sauvignon (Vitis vinifera L.) grapevine Santa Catarina highlands. Revista Ciências Agroveterinárias, Lages, v.10, n.1, p.44-53, 2011.

MALINOVSKI, L.I.; BRIGHENTI, A.F.; BORGHEZAN, M.; GUERRA, M.P.; SILVA, A.L.; PORRO, D.; STEFANINI, M.; VIEIRA, H.J. Viticultural performance of Italian grapevines in high altitude regions of Santa Catarina State, Brazil. Acta Horticulturae, The Hague, v.1115, p.202 - 210, 2016.

MARCON FILHO, J. L.; HIPÓLITO, J.S.; MACEDO, T. A.; KRETZSCHMAR, A. A.; RUFATO, L. A survey of clusters thinning in the 'Cabernet Franc' winemaking potential in two seasons. Ciência Rural, Santa Maria, v.45, n.12, p.2150 - 2156, 2015.

MIELE, A.; RIZZON, L.A.; ZANUZ, M.C. Discrimination of brazilian red wines according to the viticultural region, varietal, and winery origin. Food Science and Tecnhology, Campinas, v.30, p.268 - 275, 2010.

OIV - Office International de la Vigne et du Vin. Normes et documents techniques. Paris, 1990, v.63, p.953. Disponível em: http://www.oiv.int/fr/normes-etdocuments-techniques. 
OIV- Office International de la Vigne et du Vin. Recueil des méthodes internationales d'analyse des vins et des moûts. $2^{\text {nd }}$ ed. Paris, 2009.

RENOUF V.: TREGOAT O.; ROBY J.P.; VAN LEEUWEN C. Soils, rootstocks and grapevine varieties In prestigious Bordeaux vineyars and their impact on yield and quality. Journal International del la Sciences de la Vigne et du Vin, Bordeaux, v.44, n.3, 127 - 134, 2010.

RIBEREAU-GAYON, P.; DONÈCHE, B.; DUBORDIEU, A.; LONVAUD, A. Traide d'enologie: microbiologie du vin: vinifications. Paris: Editorial Dunod, 1998, 185p.

RIZZON, L.A. Metodologia para análise de vinho. Brasília (DF): Embrapa Informação Tecnológica, 2010. $120 \mathrm{p}$

SINGLETON, V.L.; ROSSI, J.A. Colorimetry of total phenolics with phosphomolybdic - phosphotunestic acids reagents. American Journal of Enology and Viticulture, Davis, v.16, p.144 - 158, 1965.

SMART, R.; M. ROBINSON. Sun light into wine: a handbook for winegrape canopy management. Adelaide: Ed. Winetitles, 1991. $72 \mathrm{p}$.

SOUZA, C.R.; MOTA, R.V.; FRANÇA, D.VC.; PIMENTEL, R.M.A.; REGINA, M.R. Cabernet Sauvignon grapevine grafted onto rootstocks during the autumn-winter season in southeastern Brazilian. Scientia Agricola, Piracicaba, v.72, p.138 - 146, 2015.

STEFANINI, M.; IACONO, F.; COLUGNATI, G.; BREGNANT, F.; CRESPAN, G. Adaptation of some Cabernet-Sauvignon clones to the environmental conditons of North-Eastern Italian growing areas. Acta Horticulturae, The Hague, v.528, p.779-784, 2000.
TARDAGUILA, J.; MARTINEZ, T.F.; PONI, S.; DIAGO, M.P. Impact of early leaf removal on yield and fruit and wine composition of Vitis vinifera L. Graciano and Carignan. American Journal of Enology and Viticulture, Davis, v.61, p.372 - 381, 2010.

TITA, O.; BULANCEA, M.; PAVELESCU, D.; MARTIN, $\mathrm{L}$. The role of the organic acids in the evolution of the wine. In: INTERNATIONAL CONGRESS OF CHEMICAL AND PROCESS ENGINNERING, 17., 2006. Praha. Proceedings [...]. p.27-31.

TONIETTO, J.; CARBONNEAU, A. A multicriteria climatic classification system for grape-growing regions worldwide. Agricultural and Forest Meteorology, Amsterdam, v.124, p.81 - 97, 2004.

VIANNA, L. F.; MASSIGNAN, A.M.; PANDOLFO, C.; DORTZBACH, V.F.V.Agronomic and edaphoclimatic characterization high altitude vineyards. Revista Ciência Agroveterinárias, Lages, v.15, p.215 - 226, 2016.

WURZ, D.A.; BEM, B.P.; ALLEBRANDT, R.; BONIN, B.; DALMOLIN, L.G.; CANOSSA, A.T.; RUFATO, L.; KRETZSCHMAR, A.A. New wine-growing regions of Brazil and their importance in the evolution of Brazilian wine. BIO Web Conference, Lages, v.9, p.1-4, 2017.

ZALAMENA, J.; CASSOL, P.C.; BRUNETTO, G.; GROHSKPF, M.A.; MAFRA, M.S. Nutritional status, vigor and yield of grapevines intercropped with cover crops. Revista Brasileira de Fruticultura, Jaboticabal, v.35, n.4, p.1190 - 1200, 2013.

ZAMUZ, S.; MARTÍNEZ, M. C.; VILANOVA, M. Primary study of enological variability of wines from different clones of Vitis vinifera L. cv.Albariño grown in Misión Biológica de Galicia (CSIC). Journal of Food Composition and Analysis, New York, v.20, n.7, p.591 $-595,2007$. 